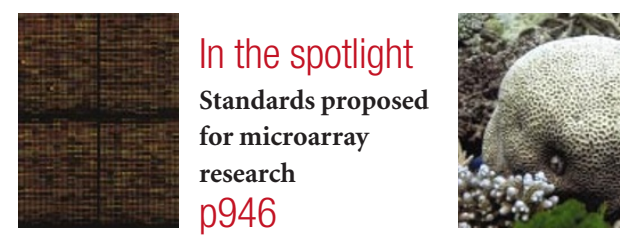

Reef encounter
Marine biologists
gather to save coral
from bleaching
p947

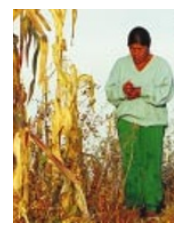

\section{Corn trouble}

Row escalates over use of genetically modified crops p948

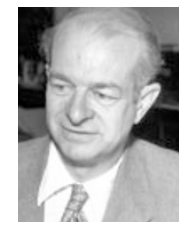

Linus online

Pauling's notebooks set to make their Internet debut p950

\title{
Nuclear-weapons design plan raises fresh proliferation fears
}

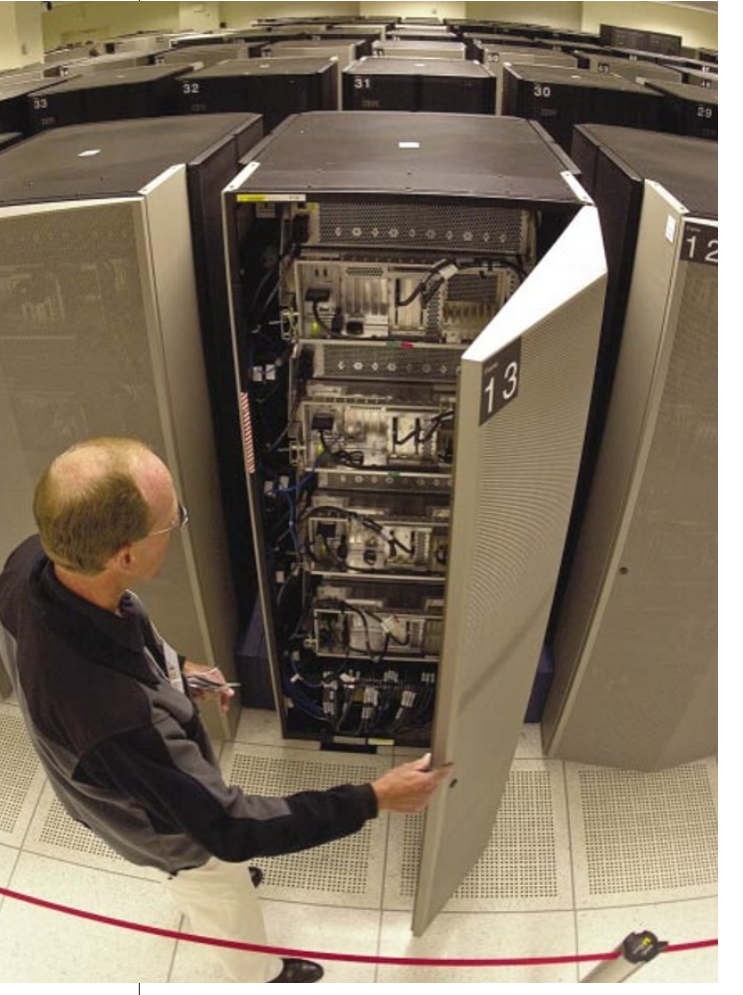

Livermore's ASCI White computer can be used to simulate nuclear weapons - old and new.
Geoff Brumfiel, Washington

The Bush administration has announced plans for the United States to resume design work on new nuclear weapons for the first time in almost a decade.

The move drew immediate fire from former nuclear-weapons designers, scientific organizations and environmental groups, who say it could undermine efforts to limit the spread of nuclear weapons.

Herbert York, a former weapons designer and arms-control advocate, says the plan has "the wrong kind of focus". York says the nuclear-weapons programme should instead be working to minimize the chances that the weapons will ever be used.

The plan was announced by John Gordon, director of the National Nuclear Security Agency (NNSA), the branch of the Department of Energy that runs the US weapons programme. "The vision is for small, focused teams to assess military requirements, investigate options and ensure that our Department of Defense partners understand what is and is not possible," Gordon told a hearing of the Senate Committee on Armed Services on 14 February.

Gordon said that, beyond assessing the needs of the armed forces, the programme will start design work on new kinds of nuclear warheads. John Harvey, director of planning at the NNSA, says: "What we're asking these teams to do is to think about what kind of things will be possible in the future."

The emphasis on weapons development is a sharp departure from the approach taken by the Clinton administration, which, from 1992 to 2000, told the weapons laboratories to concentrate on maintaining existing weapons, under the Science-Based Stockpile Stewardship programme (see Nature 387, $541 ; 1997)$. The design work during that period was largely restricted to modifying the weapons systems that carried the warhead, according to government statements.

The new plan calls for the establishment of small design teams at three US nuclear weapons laboratories - Los Alamos and Sandia in New Mexico, and Lawrence Livermore in California. Their initial focus will probably be on small, earth-penetrating warheads, in which the defence department has expressed an interest. The labs have already developed such a weapon, based on existing nuclear warheads.

The NNSA claims that the design teams are being formed largely to help train and recruit scientists and engineers. "A key element of this is to take the scientists who have developed, designed and tested new

\section{Foreign researchers turn their backs on Germany}

Quirin Schiermeier and Regina Wegner, Munich Germany continues to be an unpopular destination for young researchers from abroad, according to new figures from the European Commission (EC).

The country's lack of attractiveness to researchers has been revealed in details of the uptake of the EC's Marie Curie Fellowships, which enable European postgraduates and postdoctoral fellows to study in another country within the continent.

Only $10 \%$ of the 2,080 fellowships awarded between 1999 and 2001 were used to study at a German university, research institute or industry research programme.
The Netherlands, a country with a much smaller science base than Germany, attracts almost the same number. Britain remains the preferred country for young European scientists, attracting over one-third of new fellows.

France is a relatively popular destination, drawing $17 \%$ of new fellows. But, together with Spain, the country also has the largest number of researchers departing through the scheme. Scientists from the two nations

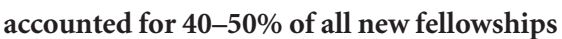
between 1999 and 2001. Both countries have a relatively small number of new postdoctoral positions available each year.
German researchers contacted by Nature say that language difficulties and the notorious bureaucracy of university administrations are to blame.

The situation is particularly difficult in eastern Germany, says Jörg Oehlmann, a toxicologist at the University of Frankfurt, who has supervised Marie Curie fellows in the past. "Many people are deterred by the fact that English is only poorly spoken and understood in eastern Germany, which can make daily life a rather adventurous experience for foreigners," he says.

| www.cordis.lu/improving/fellowships/home.htm 
warheads, and have them transfer their skills to a new generation," says Harvey. Maintaining these skills will allow the United States to respond to future threats, he adds.

But Chris Paine, an analyst at the Natural Resources Defense Council, an environmental group that keeps a close track of the US weapons programme, says that such skills are unnecessary. "This is no longer a growth industry," he says. Paine predicts that the design effort will serve to undermine non-proliferation, and encourage other countries to develop nuclear weapons of their own.

Richard Garwin, a physicist and former head of research at IBM who has advised successive US governments on nuclear-weapons policy, suggests that the design activity may ultimately lead to a resumption of nuclear testing, which the United States abandoned in 1992.

But Harvey maintains that most of the activity would be restricted to computer simulation and testing of weapon components. "Our intention would be to carry out new development consistent with the president's moratorium on testing," he says. But he concedes that the possibility of future tests remains "an open question".

\section{Power vacuum expands as CDC director resigns}

\section{Meredith Wadman, Washington}

Four of the main health administration jobs in the US government are now vacant, following Jeffrey Koplan's resignation as director of the Centers for Disease Control and Prevention (CDC) on 21 February.

As well as the CDC, the National Institutes of Health (NIH) and the Food and Drug Administration are without permanent directors. The figurehead position of surgeon general - who offers health advice to the US public — fell vacant a few weeks ago with the departure of David Satcher.

The vacancies are a source of mounting concern to health advocates, who say that the situation will take its toll on biomedical research and public health. "It's just a glaring gap in scientific leadership at a critical time," says Tony Mazzaschi, associate vicepresident for research at the Association of American Medical Colleges.

But Bill Hall, a spokesman for health secretary Tommy Thompson, says: "We have very, very competent people who are acting in those positions right now and who are doing a fantastic job."

Nevertheless, the NIH has been without a permanent director for more than two years. And in the past week Anthony Fauci, director of the National Institute of Allergy and Infectious Diseases (NIAID), has fallen out of the running for the NIH's top job. White House officials say this was because he wanted to maintain his job at the NIAID while serving as NIH director - but others contend that conservatives spiked his nomination because of his past support for fetal-tissue research.

Elias Zerhouni, a radiologist and senior administrator at Johns Hopkins University School of Medicine in Baltimore, Maryland, is now being floated as a contender for the post. But he inspired a new centre at Johns Hopkins that conducts embryonic stem-cell research, and looks as vulnerable as anyone to the political machinations that are holding up health-related appointments.

\section{Minimum standards set out for gene-expression data}

\section{Jonathan Knight, Boston}

A grassroots collection of biologists plans to persuade scientific journals to enforce minimum standards for the publication of all experiments involving microarrays.

The arrays, which monitor the expression of thousands of genes simultaneously, have proved to be helpful in the discovery of genes that influence such diverse processes as cancer and embryonic development. But whereas DNA sequences are always in the same format, microarray

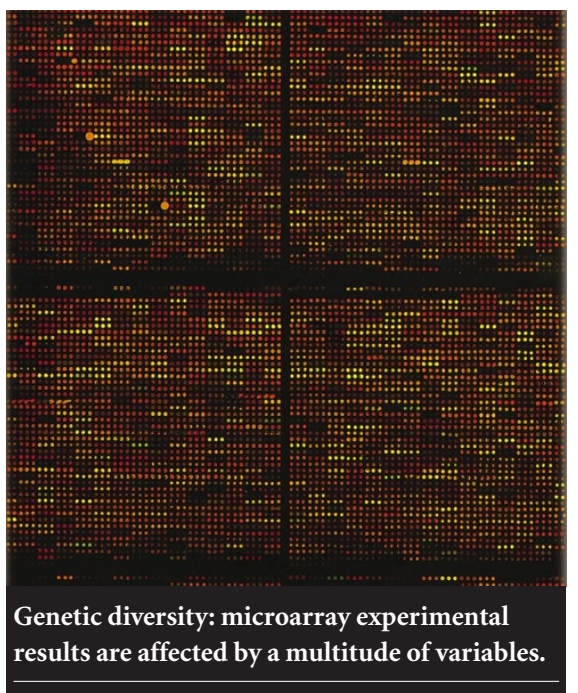

experiments are difficult to compare with one another, because of the multitude of variables that affect their outputs (see Nature 410, 851, 860-861; 2001).

In an effort to remedy this, the Microarray Gene Expression Database (MGED) Group first devised a common set of standards - called minimum information about a microarray experiment (MIAME) - in 1999.

But although many papers now refer to the MIAME standards, compliance is uneven, says Catherine Ball, curator of the Stanford Microarray Database. "At the moment, it's terrible," she says. "I often find I can't identify genes or that people have used home-grown software they don't describe."

"Generally, we want the same thing you have with published DNA sequences," says Alvis Brazma, head of microarray informatics at the European Bioinformatics Institute in Cambridge, UK. This means that all primary research data should be submitted to a repository, he says. The standards would also require the publication of enough experimental detail to allow other scientists to compare different data sets.

In early March, the MGED steering committee, of which Ball and Brazma are members, plans to release a check-list based on MIAME for use by authors, editors and referees. The list will be designed to make it easy for journals to request, and ultimately require, MIAME compliance.

The final check-list is likely to ask for details of sample preparation and data processing, as well as numerical read-outs of the intensity of the array's red and green spots, which indicate the level of gene expression.

Ball says that the check-list won't require authors to reveal every gene on an array, as this could allow others to scoop experiments in progress. "No one would argue that you should publish data prematurely," she says. "You can strip out the gene identity of things you are not publishing."

Journal editors are enthusiastic about the proposed check-list, but say that they will consult the microarray researchers before requiring authors to comply with it. "We'd consider insisting if the community showed broad consensus," says Nature's editor, Philip Campbell.

Laurie Goodman, executive editor of Genome Research, published by Cold Spring Harbor Laboratory, says that she would be cautious about requirements that could rule out important papers, but would consider adopting minimum standards if she received a strong indication that microarray users support them. nww.mged.org 